\title{
Question Items for Specific Lecture Types in College for More Adequate Student Evaluation on Instructors' Teaching Performance
}

\author{
Dr. Pyong Ho Kim¹, Dr. Sung Hee Hong ${ }^{2}$ \\ ${ }^{1}$ Assistant Professor, Early Childhood Education Department, Woosong University, Daejeon, South Korea \\ ${ }^{2}$ Assistant Professor, Early Childhood Education Department, Changshin University, Changwon, South Korea \\ 'pyonghokim@woosong.org, ${ }^{2}$ hongsh2002@hanmail.net
}

\begin{abstract}
The study attempted to propose refined question items used for eight types of lectures practiced in college settings (i.e., theory-based learning, flipped learning, discussion-based lectures, problem-based learning, co-teaching, Capstone Design, e-learning, and laboratory lectures). Its purpose was to help students objectively and accurately evaluate the lectures so that the instructors could use the data to improve their teaching effectiveness and to heighten student satisfaction. Extracting data from 15 journal publishers, the study investigated 34 articles published since 2013 in relation to lecture evaluations. Results entail different lecture evaluation question items that well match distinct features each lecture type entails. Further implications for future studies are proposed based on the findings.
\end{abstract}

Keywords : Higher education, Course evaluation items, Application for lectures, Student Satisfaction, Lecture types

\section{Dr. Sung Hee Hong}

Assistant Professor, Early Childhood Education Department, Changshin University, Changwon, South Korea hongsh2002@hanmail.net

\section{Introduction}

\subsection{The Rationale of the Study}

The history of lecture evaluation can be found in the United States in 1960's, which was implemented in order to ensure higher levels of accountability among higher education institutions, meet college students' needs, and improve quality of education provided [1]. Following this model, South Korea had begun a series of public examinations and discussions regarding a system with a purpose of evaluating professors' teaching performance since 1980 's, and the majority of universities started implementing it in the early 1990 's. Along with the emphasis on student-centered approach in higher education settings, away from instructor-centered ones (e.g., unidirectional lectures that barely involve student participation and/or discussion), universities introduced a lecture evaluation system, starting from those in Seoul metropolitan area. Currently the majority of the universities across the nation - if not every university - is underlining the importance of properly evaluating instructors' performance with purposes of measuring teaching quality, enhancing instructional skills, and heightening students' satisfaction. Further, because the results of student evaluation on instructors' teaching are weighted for a series of periodic faculty performance assessments, a considerable number of researchers have been recently involved in this field to accurately measure the results, and to ensure its reliability [2-5]. 
Educational systems that provide no or insufficient feedback to instructors are unlikely to work successfully for both groups of instructors and students. Evaluation results that are inadequately and improperly conducted regarding instructors' teaching performances in higher education could negatively affect the general lecture quality. Without proper evaluation and objective feedback, instructors could hardly identify problems they may have, resulting in continuing poor instructional performances in their lectures without improvement. From this perspective, student evaluation on instructors' teaching effectiveness are believed to keep education level higher [6]. Thus, there exists a need for refining and enhancing question items that students use as they evaluate the quality of the lectures in various portions, including the instructors' teaching effectiveness they perceive and general satisfaction levels.

\subsection{The Purpose of the Study}

The purpose of the study is to suggest proper and refined question items implemented in accordance with specific lecture types (i.e., theory-based lectures, flipped learning, discussion-based lectures, problembased learning, co-teaching, Capstone Design, elearning, and laboratory lectures). It is almost irrational to evaluate the quality of each lecture as well as that of professor based on a sole series of lecture assessment items - mostly theory-based lectures. A considerable number of universities currently implement not only theory-based learning, but other types such as flipped learning, discussion-based classes, problem-based learning, team-teaching, capstone design, e-learning, and practice-oriented classes [7]. Hence, one could expect the series of lecture assessment question items suggested in the study to be utilized in accordance with the unique needs of each type of lectures in college settings.

\section{Literature Review}

\subsection{The Purpose of Lecture Evaluation in Colleges}

The lecture evaluation systems at a university level are designed to reassure instructors to prepare for lectures in a student-centered fashion, and to help them execute the lectures based on the student feedback provided. In other words, its purpose is to mainly enhance the professors' teaching performances and to improve the quality of lectures. Most universities also use the results of the lecture evaluation as an indicator of personnel management
[8]. The results of the lecture evaluation and utilization measures are also used as major indicators in the evaluation to select various financial support projects given by the governments [9].

Lecture evaluation has two main objectives: formative and summative purposes. Formative assessment refers to collected data designed to improve lecture quality through a lecture evaluation, and the results of summative assessment are used to re-format the courses, decide whether promoting professors to a certain position or not (e.g., associate, assistant, full, etc.), re-contracting instructors for lifelong period or not, etc. [10]; these summative purposes that lecture evaluation systems serve tend to become one of the primary reasons about which instructors mind. Additionally, Han and colleagues [11] surveyed 108 universities in South Korea regarding what purposes the lecture evaluations serve; 89 replied 'improvement of lecture quality', and 63 replied 'reflection of professors' performance'. These findings exemplify that, in additional to the original purposes of enhancing quality improvement of university lectures, the evaluation systems conducted within higher education settings also serve as other objectives, such as promotion of the professors, provision of information for students' rights to decide which lectures they could register, and collection of information for course-related researches to ensure improvement of teaching effectiveness.

There exists a wide range of perspectives positive, negative, and neutral - toward the currently available lecture evaluation systems conducted within universities. Whereas some perceive that the system's methods of evaluating instructors' teaching performances generally entail a certain level of validity and usefulness for students, others argue that the system perhaps interrupt the lectures because it lacks validity. Those in the neutral positions declare that though the current evaluation system contains rooms for improvement, researches need to be conducted to make improvements. In sum, it is hard to articulate that the lecture evaluation method that relies on students' opinions is not feasible enough to the point that universities need to exclude the system completely; on the other hand, it is also difficult to regard the system as a reasonable indicator to fully trust as a valid tool to evaluate the general lecture quality [10].

Additionally, Yang [12] asserted that purpose of the lecture evaluation is threefold: i) encouraging the 
instructors to make efforts to reflect students' opinions on their teaching practice, ii) reminding the instructors of the importance of effectively conducting lectures for students' success, which has been relatively neglected compared to research skills, and iii) improving teaching quality by helping the instructors objectively examining their lectures.

2.2. Three Problems Related to the Current Lecture Evaluation System

Although the students' evaluation on instructors at a higher education level is used as a major indicator of the education and lecture quality, there still exist problems related to the evaluation system, tools, and question items in practice.

Frist, the lack of in-depth research on the validity or reliability of the question items raise the issue of fairness, but also cause confusion as to providing (in)correct information about the instructors [13]. Also, the fact that Korean universities often implement evaluation question items imported from American lecture evaluation systems causes problems because the higher education settings are clearly different in the two countries. Though the validity and reliability in the United States showed a high level of feasibility, the results may differ in South Korea [6]. Considering that it has been more than 20 years since Korean universities began conducting lecture evaluations, one could argue the necessity of utilizing the existing data to develop more realistic and optimal question items.

Second, many of the lecture evaluation question items fail to correctly evaluate students' responses to the feasibility of assignments given, overall satisfaction of the course, and appropriateness of the grades given [13]. Although these factors entail the validity in quantifying instructors' teaching practice, the items aforementioned often neglect whether the students properly learn the contents delivered during the lectures.

Third, the lecture evaluation implemented in most of Korean universities include the following question items: instructors' preparedness, passion for the lectures, encouraging student participation, feasibility of assignments given, processing the lectures according to syllabus, students' overall satisfaction, and appropriateness of grades given. Whereas these factors attempt to quantify the instructors' competency in lecturing, they tend to neglect the degree to which students properly learn. The existing evaluation items generally do not determine whether the course objectives (e.g., understanding the basic concepts, developing student competencies, being able to creatively solve given problems) were accomplished [10].

Additionally, Park (2012) [14] pointed out the following as the problems of currently practiced lecture evaluation: the weak relationship between the evaluation categories and the question items, the uncertainty of the scope of the evaluation, the overlap of information to be obtained through the answer to the question, and the ambiguity of the distinction between the evaluation categories. In order for lecture evaluation questions to serve its original purpose, development of proper question items that secure credibility is necessary. It needs to reflect the characteristics of various types of lectures practiced in higher education settings, considering its particular traits of teaching and learning environments.

2.3 The Validity and Reliability of Lecture Evaluation Results

The validity of the lecture evaluation refers to the degree to which the question items meets the purpose in relation to its evaluation purpose. To attain the credibility of the lecture evaluation, it is necessary to clearly articulate the purpose of the lecture evaluation, and clarify the factors applied in the lecture evaluation $[15,16]$. The purpose of the lecture evaluation is to improve the lecture by providing feedback to the instructors, and to have them use it as a fundamental material for compensation (e.g., promotion) and penalty (e.g., retrenchment). In order for the evaluation question items to be valid, they must meet these purposes. Reliability refers to the degree to which the results of the lecture evaluation are consistent. To substantiate it, one could apply the testre-test method to verify: (1) the stability of the test results, (2) the reliability of the test to measure the homogeneity of the test, and (3) the consistency of the questions within the question [17]. Measuring the consistency of the participants' responses for course evaluation is another important factor of reliability.

\section{Method}

The study attempted to improve lecture assessment question items for various types of lectures that can be implemented in college settings, and to utilize the results improve the lectures as well as professors' 
teaching expertise. To this end, the author categorized the eight types of lectures conducted in Korean university settings; these included (1) theory-based lectures, (2) flipped learning, (3) discussion-based lectures, (4) problem-based learning (PBL), (5) Capstone Design, (6) e-learning, (7) co-teaching, and (8) experimental lectures. In fact, the main target of the method is to determine the replicability of the study. Extracting data from 11 legitimate journal publishers and four(4) university-level websites on themes of teaching methods and evaluation in higher education settings, the study investigated 34 articles published since 2013. The articles that seemed irrelevant to the purpose of the study were excluded. The categories of each lecture type included 'Evaluation on the Lecturer', but other factors that the searched article suggested, and the questions proposed in the articles are presented in the Results section.

The details of the research procedures is shown in [Table 1], applying a timeline format.

Table 1 : Learning Media Evaluation Result by AutoCAD 3D Material

\begin{tabular}{|c|c|c|}
\hline Category & Stage & Contents \\
\hline \multirow{10}{*}{$\begin{array}{l}\text { Conducting } \\
\text { literature } \\
\text { research } \\
\text { activities }\end{array}$} & \multirow{6}{*}{$\begin{array}{l}\text { Collecting } \\
\text { preliminary } \\
\text { data }\end{array}$} & $\begin{array}{l}\text { Conducting literature review } \\
\text { and organizing articles (1) }\end{array}$ \\
\hline & & $\begin{array}{l}\text { Conducting literature review } \\
\text { and organizing articles (2) }\end{array}$ \\
\hline & & $\begin{array}{l}\text { Conducting literature review } \\
\text { and organizing articles (3) }\end{array}$ \\
\hline & & $\begin{array}{l}\text { Selecting question items for } \\
\text { theory-based lectures, flipped } \\
\text { learning, and discussion-based } \\
\text { learning }\end{array}$ \\
\hline & & $\begin{array}{l}\text { Selecting question items for } \\
\text { problem-based learning(PBL) } \\
\text { and Capstone Design }\end{array}$ \\
\hline & & $\begin{array}{l}\text { Selecting question items for e } \\
\text { learning, co-teaching, and } \\
\text { experimental lectures }\end{array}$ \\
\hline & \multirow{4}{*}{$\begin{array}{l}\text { Exchanging } \\
\text { feedback }\end{array}$} & $\begin{array}{l}\text { Making a report to the } \\
\text { University's Center for } \\
\text { Teaching and Learning (CTL) }\end{array}$ \\
\hline & & $\begin{array}{l}\text { Making revisions based on } \\
\text { feedback provided by CTL (1) }\end{array}$ \\
\hline & & $\begin{array}{l}\text { Making revisions based on } \\
\text { feedback provided by CTL ( } 2 \text { ) }\end{array}$ \\
\hline & & $\begin{array}{l}\text { Making revisions based on } \\
\text { feedback provided by CTL ( } 3 \text { ) }\end{array}$ \\
\hline $\begin{array}{l}\text { Completing the } \\
\text { study }\end{array}$ & $\begin{array}{l}\text { Completing } \\
\text { the study }\end{array}$ & $\begin{array}{l}\text { Finalizing the question items } \\
\text { for the study }\end{array}$ \\
\hline
\end{tabular}

\section{Results}

4.1 Suggested question items for each type of lectures

\subsubsection{Theory-based lectures}

The theory-based lectures contain the following evaluation question items as shown in [Table 2] [1820]. Additionally, this would be used as a common set of evaluation items that are applied to all lecture types.

Table 2 : Lecture Evaluation Question Items for Theory-based Lectures [18-20]

\begin{tabular}{|c|c|}
\hline Category & Content \\
\hline \multirow{3}{*}{$\begin{array}{l}\text { Organization } \\
\text { of } \\
\text { Expectation } \\
\text { for the } \\
\text { Instructor }\end{array}$} & 1) Learning objectives were clearly stated. \\
\hline & $\begin{array}{l}\text { 2) This course was systematically managed } \\
\text { and proceeded according to the learning } \\
\text { objectives. }\end{array}$ \\
\hline & $\begin{array}{l}\text { 3) The lectures were conducted to achieve } \\
\text { the initially stated learning objectives. }\end{array}$ \\
\hline \multirow{4}{*}{$\begin{array}{l}\text { Textbooks, } \\
\text { Grades, and } \\
\text { Lecture } \\
\text { Management }\end{array}$} & $\begin{array}{l}\text { 4) The textbook and other supplementary } \\
\text { material were applied properly. }\end{array}$ \\
\hline & $\begin{array}{l}\text { 5) The examinations, quizzes, and } \\
\text { assignments were helpful to achieve the } \\
\text { initially stated learning objectives. }\end{array}$ \\
\hline & $\begin{array}{l}\text { 6) The course's level of difficulty was } \\
\text { managed appropriately. }\end{array}$ \\
\hline & $\begin{array}{l}\text { 7) The amount of contents conveyed during } \\
\text { lectures was appropriate. }\end{array}$ \\
\hline \multirow{3}{*}{$\begin{array}{l}\text { Evaluation } \\
\text { on the } \\
\text { Instructor }\end{array}$} & $\begin{array}{l}\text { 8) The feedback the lecturer provided } \\
\text { regarding the assignment or examination } \\
\text { was helpful. }\end{array}$ \\
\hline & $\begin{array}{l}\text { 9) The lecturer demonstrated proper amount } \\
\text { of knowledge for the course. }\end{array}$ \\
\hline & $\begin{array}{l}\text { 10) The lecturer did not cancel a lecture. } \\
\text { When necessary, s/he provided a make- } \\
\text { up lecture. }\end{array}$ \\
\hline \multirow{3}{*}{$\begin{array}{l}\text { Self- } \\
\text { evaluation* }\end{array}$} & $\begin{array}{l}\text { 11) I attempted to participate actively in the } \\
\text { course. }\end{array}$ \\
\hline & $\begin{array}{l}\text { 12) I attempted to prepare myself for each } \\
\text { lecture in advance. }\end{array}$ \\
\hline & 13) I submitted each assignment on time. \\
\hline
\end{tabular}

* The results of this section do not apply to evaluate the instructors' teaching performance.

\subsubsection{Flipped Learning}

The flipped learning lectures contain the following evaluation question items as shown in [Table 3] [21]. 


\section{Table 3 : Lecture Evaluation Question Items for Flipped Learning [21]}

\begin{tabular}{|c|c|}
\hline Category & Content \\
\hline \multirow{3}{*}{$\begin{array}{l}\text { Improvement } \\
\text { of My } \\
\text { Competencies }\end{array}$} & 1) I was able to improve my analysis skill. \\
\hline & $\begin{array}{l}\text { 2) I was able to improve my problem- } \\
\text { solving skill. }\end{array}$ \\
\hline & $\begin{array}{l}\text { 3) I was able to improve my skill of } \\
\text { suggesting solutions for unfamiliar } \\
\text { problems. }\end{array}$ \\
\hline \multirow{2}{*}{$\begin{array}{l}\text { Cooperation } \\
\text { with the } \\
\text { Colleagues }\end{array}$} & $\begin{array}{l}\text { 4) I learned that my contribution to the } \\
\text { team as a member is important. }\end{array}$ \\
\hline & $\begin{array}{l}\text { 5) I learned that it is important for me to } \\
\text { cooperate with the team members in } \\
\text { order to successfully carry out a team } \\
\text { project. }\end{array}$ \\
\hline \multirow{2}{*}{$\begin{array}{l}\text { Evaluation on } \\
\text { the Instructor }\end{array}$} & $\begin{array}{l}\text { 6) The instructor sufficiently explained } \\
\text { about the teaching and learning method } \\
\text { of flipped learning. }\end{array}$ \\
\hline & $\begin{array}{l}\text { 7) The instructor attempted to engage } \\
\text { uninterested learners in the lectures. }\end{array}$ \\
\hline \multirow{3}{*}{$\begin{array}{l}\text { Self- } \\
\text { evaluation* }\end{array}$} & $\begin{array}{l}\text { 8) I attempted to participate actively in the } \\
\text { course. }\end{array}$ \\
\hline & $\begin{array}{l}\text { 9) I attempted to prepare myself for each } \\
\text { lecture in advance. }\end{array}$ \\
\hline & 10) I submitted each assignment on time. \\
\hline
\end{tabular}

* The results of this section do not apply to evaluate the instructors' teaching performance.

\subsubsection{Discussion-based Lectures}

The discussion-based lectures contain the following evaluation question items as shown in [Table 4] [22-23].

Table 5 : Lecture Evaluation Question Items for Discussion-based Lectures [22-23]

\begin{tabular}{|c|c|}
\hline Category & Content \\
\hline \multirow{3}{*}{$\begin{array}{l}\text { Improvement } \\
\text { of My } \\
\text { Competencies }\end{array}$} & $\begin{array}{l}\text { 1) I was able to organized my thoughts and } \\
\text { verbally express myself to the others. }\end{array}$ \\
\hline & $\begin{array}{l}\text { 2) I was able to improve my skill of } \\
\text { accommodating various perspectives. }\end{array}$ \\
\hline & 3) I was able to improve my critical thinking skill. \\
\hline \multirow{3}{*}{$\begin{array}{l}\text { Evaluation on } \\
\text { the Instructor }\end{array}$} & $\begin{array}{l}\text { 4) The instructor attempted to provide the } \\
\text { students with an equal amount of } \\
\text { opportunities to freely speak. }\end{array}$ \\
\hline & $\begin{array}{l}\text { 5) The instructor successfully played a role of } \\
\text { moderator the discussion was conducted in a } \\
\text { balanced fashion. }\end{array}$ \\
\hline & $\begin{array}{l}\text { 6) The instructor prepared appropriate themes for } \\
\text { the discussion. }\end{array}$ \\
\hline
\end{tabular}

Evaluation on 7) The instructor attempted to engage

the Instructor uninterested learners in the lectures.

8) I attempted to participate actively in the course.

Selfevaluation*

9) I attempted to prepare myself for each lecture in advance.

10) I submitted each assignment on time.

* The results of this section do not apply to evaluate the instructors' teaching performance.

\subsubsection{Problem-based Learning (PBL)}

The problem-based learning (PBL) lectures contain the following evaluation question items as shown in [Table 5] [24].

Table 5 : Lecture Evaluation Question Items for Problem-based Learning [24]

\begin{tabular}{c|l}
\hline Category & \multicolumn{1}{|c}{ Content } \\
\hline \hline \multirow{2}{*}{$\begin{array}{c}\text { Improvement } \begin{array}{c}\text { 1) I was able to improve planning skills prior to } \\
\text { performing. }\end{array} \\
\text { Competencies }\end{array}$} & $\begin{array}{l}\text { 2) I was able to improve problem } \\
\text { without replying on others. }\end{array}$ \\
\hline \multirow{4}{*}{$\begin{array}{c}\text { Evaluation on } \\
\text { the Instructor }\end{array}$} & $\begin{array}{l}\text { 3) The instructor showed more interests in my } \\
\text { problem-approaching methods than my } \\
\text { memorizing skills. }\end{array}$ \\
\cline { 2 - 2 } $\begin{array}{c}\text { 4) The instructor suggested a wide range of } \\
\text { problems to students. }\end{array}$ \\
\cline { 2 - 2 } to real- and everyday- lives.
\end{tabular}

* The results of this section do not apply to evaluate the instructors' teaching performance.

\subsubsection{Capstone Design}

The Capstone Design lectures contain the following evaluation question items as shown in [Table 6] [25,26].

Table 6 : Lecture Evaluation Question Items for Capstone Design [25,26]

\begin{tabular}{c|c}
\hline Category & Content \\
\hline \hline $\begin{array}{c}\text { Improvement } \\
\text { of My }\end{array}$ & $\begin{array}{c}\text { 1) I was able to improve my competencies } \\
\text { needed for planning researches. }\end{array}$ \\
\cline { 2 - 2 } Competencies & $\begin{array}{c}\text { 2) I was able to improve my competencies } \\
\text { needed for defining problems. }\end{array}$ \\
\hline
\end{tabular}


3) The instructor emphasized the importance of relationship between the theory and the field.

4) The instructor descripted in details the characteristics we will encounter on the

Evaluation on field prior to experiencing it.

the Instructor 5) The instructor helped me understand the engineering design process.

6) The instructor taught what preparations are necessary prior to experiencing the field.

7) I attempted to participate actively in the course.

Selfevaluation*

8) I attempted to prepare myself for each lecture in advance.

9) I submitted each assignment on time.

* The results of this section do not apply to evaluate the instructors' teaching performance.

\subsection{6 e-Learning}

The e-learning lectures contain the following evaluation question items as shown in [Table 7] [27].

Table 7 : Lecture Evaluation Question Items for e-Learning [27]

\begin{tabular}{|c|c|}
\hline Category & Content \\
\hline \multirow{6}{*}{$\begin{array}{l}\text { Evaluation on } \\
\text { the Instructor }\end{array}$} & $\begin{array}{l}\text { 1) The instructor attempted to respond } \\
\text { to students' questions quickly. }\end{array}$ \\
\hline & $\begin{array}{l}\text { 2) The information provided by the } \\
\text { instructor was easy to understand } \\
\text { without additional explanation. }\end{array}$ \\
\hline & $\begin{array}{l}\text { 3) The instructor clearly described the } \\
\text { assignments and test methods. }\end{array}$ \\
\hline & $\begin{array}{l}\text { 4) When additional information was } \\
\text { necessary, the instructor notified } \\
\text { the students in advance. }\end{array}$ \\
\hline & $\begin{array}{l}\text { 5) The instructor attempted to } \\
\text { encourage unmotivated students to } \\
\text { participate in the course. }\end{array}$ \\
\hline & $\begin{array}{l}\text { 6) The instructor was competent in } \\
\text { using technological devices. }\end{array}$ \\
\hline \multirow{3}{*}{$\begin{array}{l}\text { Self- } \\
\text { evaluation* }\end{array}$} & $\begin{array}{l}\text { 7) I attempted to participate actively in } \\
\text { the course. }\end{array}$ \\
\hline & $\begin{array}{l}\text { 8) I attempted to prepare myself for } \\
\text { each lecture in advance. }\end{array}$ \\
\hline & 9) I submitted each assignment on time. \\
\hline
\end{tabular}

* The results of this section do not apply to evaluate the instructors' teaching performance.

\subsubsection{Co-teaching}

The co-teaching lectures contain the following evaluation question items as shown in [Table 8] [28].

Table 8 : Lecture Evaluation Question Items for Co-teaching [28]

\begin{tabular}{c|c}
\hline Category & \multicolumn{1}{c}{ Content } \\
\hline \hline \multirow{4}{*}{$\begin{array}{c}\text { Evaluation on } \\
\text { the Instructors }\end{array}$} & $\begin{array}{c}\text { 1) The instructors shared the common } \\
\text { course objectives. } \\
\text { 2) The instructors consistently taught the } \\
\text { course. }\end{array}$ \\
\cline { 2 - 2 } expertise.
\end{tabular}

* The results of this section do not apply to evaluate the instructors' teaching performance.

\subsubsection{Experimental Lectures}

The experimental lectures contain the following evaluation question items as shown in [Table 9] [29].

Table 9: Lecture Evaluation Question Items for Experimental Lectures [29]

\begin{tabular}{|c|c|}
\hline Category & Content \\
\hline \multirow{2}{*}{$\begin{array}{l}\text { Improvement } \\
\text { of My } \\
\text { Competencies }\end{array}$} & $\begin{array}{l}\text { 1) I was able to improve my skills needed } \\
\text { for planning and proceeding } \\
\text { experiments. }\end{array}$ \\
\hline & $\begin{array}{l}\text { 2) I was able to improve my skills needed } \\
\text { for analyzing the results and reaching } \\
\text { conclusions. }\end{array}$ \\
\hline $\begin{array}{l}\text { Evaluation on } \\
\text { the Instructor }\end{array}$ & $\begin{array}{l}\text { 3) The instructor thoroughly prepared } \\
\text { devices and equipment needed for the } \\
\text { experiments. }\end{array}$ \\
\hline
\end{tabular}

4) The instructor demonstrated how each experiment needs to be conducted. 
5) The instructor did his/her best to ensure the students' safety during the

Evaluation on experiments.

the Instructor

6) The instructor provided the students with proper and thorough guidelines for each experiment.

7) I attempted to participate actively in the course.

Self- 8) I attempted to prepare myself for each evaluation* lecture in advance.

9) I submitted each assignment on time.

10) The laboratory was well equipped with sufficient resources.

Others*

11) The laboratory was a proper environment to conduct experiments.

* The results of this section do not apply to evaluate the instructors' teaching performance.

\section{Discussion}

The study attempted to develop lecture assessment question items that could accurately reflect the distinct features of various types of lectures conducted in Korean universities, resulting in improving teaching quality and effectiveness of instructors. In order to enhance the reliability and validity of the lecture evaluation, the lecture questions were composed of common questions and lecture type questions by including the question items that could correctly reflect the characteristics of each lecture type in the assessment. However, such attempts add the number of type-specific question items, resulting in negatively affecting the lecture assessment results because it may increase students' fatigue as they answer all the items. In order to cope with such possible problems, additional measures may be necessary to ensure the reliability of the lecture evaluation if the lecture assessment is conducted by adding questions by type. The assessment question items suggested in the study include self-assessment items for students. Since the score of the selfassessment question items is not included in the lecture assessment score, it is not directly reflected in the score, but it can be used as a data to improve the lecture as it can identify students' participation in the class.

\section{Conclusion and Implications}

\subsection{Implications of the Study}

The lecture assessment systems currently conducted in college settings are mostly regarding individual instructor's performance level that students perceive. Considering the fact that there exists a number of systematical and environmental factors influencing the lecture assessment results based on its types, it could be difficult to assess the overall education quality solely individual instructor's teaching effectiveness. To cope with such circumstances, university-level policy makers need to place efforts on refining lecture assessment questioning items as well as examining both instructors' and students' needs for each lecture type. Though the major purpose of improving question items for lecture assessment is to improve instructors' teaching effectiveness, it should aim to heighten students' satisfaction as well.

\subsection{For Future Studies}

Future researchers interested in pursuing this matter may consider the following implications. First, in order to enhance validity of lecture assessment items, a wider range of evaluation criteria needs to be studied. Its examples include self-assessment, peer evaluation, evaluation by fellow instructors, etc. It is also considered important to encourage students to participate in answering lecture assessment question items actively and sincerely. Second, researchers need to study how instructors could more effectively utilize the lecture assessment results (e.g., to what degree should the results be revealed, how the results should be utilized to reflect the instructors' reputation, etc.). Third, in addition to the attempts to accurately assess lecture quality, a series of university-level supports need to be practiced to improve instructors' teaching effectiveness.

Additionally, a number of studies have been conducted to examine factors that affect the assessment result scores of lectures [30-33]. In particular, the number of students in each lecture has been considered as a steady component affecting the assessment results [34]; the smaller class sizes, the higher scores, and the lowest scores were resulted from a lecture that contains between 90 and 100 students. Such findings may suggest that there could exist a wide range of variables that could possibly affect the quality of lectures. These findings suggest that various factors may affect the evaluation results of lectures. Currently, since lecture evaluation scores are being used not only to improve lecture quality, but also to evaluate professors' teaching effectiveness, it is 
important to objectively explore the factors that affect lecture evaluation scores based on data, and discuss the corresponding measures.

\section{Acknowledgments}

This research paper was supported by Woosong University's Academic Research Funding 2020 and Kyonggi University.

\section{References}

[1] Nam, Won-mok \& Cho, Eun-sung. "Analysis of 'Better Class' Characteristics and Patterns from College Lecture Evaluation by Longitudinal Big Data". International Journal of Contents 15.3 (2019): 7-12

[2] Park, Hong-rak. "A Study on the Improvement of a Lecture Evaluation Tool in Higher EducationA case of improvement of a lecture evaluation questionnaire." Journal of the Korea AcademiaIndustrial Cooperation Society 13.11 (2012): 5033-5043.

[3] Yang, Hoe-chang. "The Effects of Students' Cognition of Their College and Department's Core Competencies and Collective-efficacy on Satisfaction and GPA." Asia-Pacific Journal of Educational Management Research 1.1 (2016): 51-56.

[4] Hur, Youngju. "Analysis of Satisfaction and Needs in College Education of Elementary and Middle School Teachers." Asia-Pacific Journal of Educational Management Research 2.1 (2017):23-28.

[5] Lee, Myungsook \& Yang, Aekyeong. "Factors Influencing to 21st Century Skill of College Student. Asia-Pacific Journal of Educational Management Research 4.2 (2019): 7-14.

[6] Wachtel, Howard K. "Student evaluation of college teaching effectiveness: A brief review." Assessment \& Evaluation in Higher Education 23.2 (1998): 191-212

[7] Emery, Charles R., Kramer, Tracy R., \& Tian, Robert G. "Return to academic standards: A critique of student evaluations of teaching effectiveness." Quality Assurance in Education 11.1 (2003):37-46.
[8] Ko, Eun-mi., Lee, Hye-kyoung., \& Han, Eunyoung. "A Study for Development of the Course Evaluation Tool for College Lecture Types." The Journal of Humanities 31 (2013): 365-394.

[9] English, John. \& English, Tammy. "Combining summative and Formative Evaluation using Automated Assessment." Issues in Informing Science \& Information Technology 16 (2019): 141-151.

[10] Lee, Jong-gook. "A Study on the Improvement of a Lecture Evaluation Questionnaire in the University." Korean Journal of General Education 7.6(2013): 247-274.

[11] Han, Seung-il., Kim, Hyun-joo, \& Lee, Jaeyoung. "A Comprehensive Study of Korean Students' Evaluations of University Teaching." The Journal of Educational Administration 23.3 (2005): 379-403.

[12] Yang, Mi-kyoung. "Evaluations of University Teaching: significance and problems." The Korean Society for the Study Educational Principles 13.1 (2008): 93-122.

[13] Kim, Myoung-hyun. "Validity and Reliability of Lecture Evaluation." Asia Pacific Education Review 6.3 (2005): 1-24.

[14] Park. Hyo-ryun. "A Study on the Improvement of a Lecture Evaluation Tool in Higher Education A case of improvement of a lecture evaluation questionnaire in "A" university." Korea Academic-Industrial Cooperation Society 13.11 (2012): 5033-5043.

[15] Amuche, Amuche Christian Igomu \& Umar, Mahmood Hamid. "Development and Validation of Lecturer Teaching Assessment Scale for Nigerian Universities." Development 10.5 (2019): 58-69.

[16] Park, Sung-moo. "A Study for Development and Validation of the 'Course Evaluation' Scale for Learner-centered." Journal of Fisheries and Marine Science Education 23.1 (2011): 13-22.

[17] Spehl, Marco S, Straub, Christine, Heinzmann, Andrea, \& Bode, Sebstian F. "Student-perceived exam difficulty may trump the effects of different quality improvement measures 
regarding the students' evaluation of a pediatric lecture series." BMC Medical Education 19.1 (2019): 206-213.

[18] Arreola, Raoul Albert. "Developing a Comprehensive Faculty Evaluation System." Magna Publications (2004): Madison, WI, USA.

[19] DiVall, Margarita, Barr, Judith, Gonyeau, Michael, Matthews, James, van Amburgh, Jenny, Qualters, Donna, \&Trujillo, Jennifer. "Follow-up Assessment of a Faculty Peer Observation and Evaluation Program." American Journal of Pharmaceutical Education 76.4 (2012): 1-7.

[20] Ojennus, Deanna Dahlke. "Assessment of Learning Gains in a Flipped Biochemistry Classroom." Biochemistry and Molecular Biology Education 44.1 (2016): 20-27.

[21] Davies, Martin, Hirschberg, Joe, Lye, Jenny, Johnston, Carol, and McDonald, Ian. "Is It Your Fault? Influences on Student Evaluations on Teaching in Tertiary Institutions." Australian Journal of Education 43.2 (2005): 1-16.

[22] Kifle, Temesgen \& Alauddin, Mohammad. "What Determines Students' Perceptions in Course Evaluation Rating in Higher Education?" An Econometric Exploration. Economic Analysis and Policy 52 (2016): 123-130.

[23] Hassan, Abu, Ariffin, Mohd, Hamid, Abd, Hassim, Mimi Haryani, Abdul, \& Helmi, Sabdula "A Review and Survey of Problembased Learning Application in Engineering Education." Conference on Engineering Education, Kuala Lumpur, Malaysia (2004): 115.

[24] Corwin, Lisa, Runyon, Christopher, Robinson Aspen, \& Dolan Erin L. "The laboratory course assessment survey: a tool to measure three dimensions of research-course design." Life Sciences Education 14 (2015): 1-1

[25] Sobek, DK \& Jain, Vikas K. "Two instruments for assessing design outcomes of capstone projects." In Proceeding of the 2004 American Society for Engineering Education Annual Conference and Exposition (2004):1-13.
[26] Meyer, David G. "Capstone design outcome assessment: Instruments for quantitative evaluation." In Proceedings Frontiers in Education 35th Annual Conference (2005):F4DF4D.

[27] Ruiz, Jorge G., Mintzer, Michale J., \& Leipzig, Rosanne M. "The impact of e-learning in medical education."Academic Medicine 81.3 (2006): 207-212.

[28] Carty, Audrey \& Marie-Farrell, Ann. "Co-teaching in a mainstream post-primary mathematics classroom: an evaluation of models of co-teaching from the perspective of the teachers." Support for Learning 33.2 (2018): 101-121.

[29] Kim, Pyong-ho. "Suggestions for Lecture Assessment Items in College Settings." Journal of Education and Social Science 1(2020): 7-14.

[30] Mohammed, Tayfour Abdalla \& Pandhiani, Sijraj Muhammed. "Analysis of factors affecting student evaluation of teaching effectiveness in Saudi higher education: the case of Jubail University college." American Journal of Educational Research 5.5 (2017): 464-475.

[31] Yew, Tee Meng, Jen, Leong Siok, Dawood, Fauziah KP, \& Hoay, Kuan Chin. "Designing an Instrument for Providing Better Student Feedback on Teaching Effectiveness." MOJES: Malaysian Online Journal of Educational Sciences 3.1 (2018): 14-22.

[32] Anshuman, Naik, Shashikala, Patel, \& Brijesh, Mukherjee. "Improvement of Quality of Lecture by Feedback from Students." International Journal of Innovative Research in Medical Science 4.12 (2019): 694-695.

[33] Cho, Jae-seung. "Determinants of Student Course Evaluation Using Hierarchical Linear Model." Journal of the Korean Data and Information Science Society 24.6 (2013): 12851296.

[34] Carlfjord, Siw, Roback, Kerstin, \&Nilsen, Per. "Five Years' Experience of an Annual Course on Implementation Science: An Evaluation among Course Participants." Implementation Science 12.1 (2017): 101-108. 